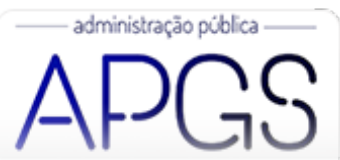

Administração Pública e Gestão Social ISSN: 2175-5787

apgs@ufv.br

Universidade Federal de Viçosa

Brasil

Retrato da inadimplência dos beneficiários da Faixa 1 do "Minha Casa, Minha Vida": análise da associação da inadimplência com variáveis socioeconômicas e de gerenciamento financeiro

\author{
dos Santos Fraga, Luana; Mendes Vieira, Kelmara \\ Retrato da inadimplência dos beneficiários da Faixa 1 do "Minha Casa, Minha Vida": análise da associação da \\ inadimplência com variáveis socioeconômicas e de gerenciamento financeiro \\ Administração Pública e Gestão Social, vol. 11, núm. 3, 2019 \\ Universidade Federal de Viçosa, Brasil \\ Disponível em: http://www.redalyc.org/articulo.oa?id=351559268006
}

Esta obra está bajo una Licencia Creative Commons Atribución-NoComercial-SinDerivar 3.0 Internacional 


\title{
Retrato da inadimplência dos beneficiários da Faixa 1 do "Minha Casa, Minha Vida”: análise da associação da inadimplência com variáveis socioeconômicas e de gerenciamento financeiro
}

\author{
Default situation of range-1 "Minha Casa, Minha Vida" beneficiaries: analysis of the association of default with \\ socioeconomic and financial management variables.
}

Retrato del incumplimiento de los beneficiarios de la franja 1 de "Minha Casa, Minha Vida": análisis de la asociación de mora con variables socioeconómicas y de gerencia financiera.

Luana dos Santos Fraga

Pontifícia Universidade Católica do Rio Grande do Sul, Redalyc: http://www.redalyc.org/articulo.oa? Brasil

luana.fraga92@gmail.com

\author{
Kelmara Mendes Vieira \\ Universidade Federal de Santa Maria, Brasil \\ kelmara@terra.com.br
} id $=351559268006$

\section{Resumo:}

O estudo tem como objetivo apresentar um retrato da situação de inadimplência de beneficiários da Faixa I do Programa Minha Casa Minha Vida. Investiga-se também as práticas de gerenciamento financeiro e a associação deste e de variáveis socioeconômicas com a inadimplência. Para tanto, foram realizadas entrevistas com 155 beneficiários de Santa Maria, no Rio Grande do Sul, e utilizada estatística descritiva, teste de diferença de média, análise de confiabilidade e teste de hipótese de associação entre variáveis. Verificou-se que os principais motivos da inadimplência são o uso do dinheiro em despesas inesperadas e atraso no envio dos boletos pela Caixa Econômica Federal. Os inadimplentes apresentam comportamento menos adequado em relação aos gastos, dívida e poupança e atitudes ao endividamento, principalmente ao acharem que é normal as pessoas ficarem endividadas para pagarem suas contas e comprar parceladamente.

Palavras-CHAVE: Habitação, Inadimplência, Gerenciamento Financeiro.

\section{Abstract:}

The study aims to present the default situation of Range 1 from Minha Casa Minha Vida Program beneficiaries. It also investigates the financial management practices and the association of this and socioeconomic variables with the default. In order to achieve this information, we interviewed 155 beneficiaries from Santa Maria, in Rio Grande do Sul, Brazil, using a descriptive statistics, mean difference test, reliability analysis and hypothesis test association between variables. It was found that the main reasons for defaults are the use of money in unexpected expenses and ticket delivery delays. Defaulters have less appropriate behavior in what comes to debt and savings, and attitudes to indebtedness.

KEYWORDS: Habitation, Default, Financial Management.

\section{Resumen:}

El estudio tiene como objetivo presentar un retrato de la situación de incumplimiento de beneficiarios de la Faja 1 del Programa "Minha Casa Minha Vida". Se investiga también las prácticas de gestión financiera y la asociación de esta y de variables socioeconómicas. Para tanto fueron realizadas entrevistas con 155 beneficiarios de Santa Maria, en Rio Grande do Sul, Brasil, y utilizada la estadística descriptiva, prueba de diferencia media, análisis de confiabilidad y prueba de hipótesis de asociación entre variables. Se verificó que los principales motivos del incumplimiento son los gastos inesperados y atrasos de facturas. Los morosos presentan comportamiento menos adecuado en relación con gastos, deudas y ahorros y actitudes al endeudamiento.

Palabras Clave: Habitación, Mora, Gerencia Financiera . 


\section{INTRODUÇÃO}

Ao longo dos anos tem sido reconhecido o fato de que moradia é uma necessidade básica de todo ser humano e faz de cada família, independente de sua renda, uma demandante em potencial do bem habitação. Diante disso, esquemas de financiamento habitacionais de longo prazo ajudam a diminuir o déficit de habitação e melhoram a vida da população (Ramos \& Noia, 2016). Nesse sentido, em 2009, foi implantado o Programa Minha Casa Minha Vida (PMCMV), com os objetivos de atender às necessidades de moradia da população com diferentes níveis de renda, gerar empregos através de novos investimentos na construção civil, combater o déficit habitacional, impulsionar a economia e proporcionar oportunidades de desenvolvimento para o país (Caixa Econômica Federal - CEF, 2015a).

Contudo, apesar dos altos subsídios do governo para as famílias com menor renda, é necessário o pagamento das prestações da casa adquirida por um longo período de tempo, correndo o risco de perder o imóvel caso não sejam pagas as prestações em dia. Para as famílias pertencentes à Faixa 1 do Programa (renda mensal de até $\mathrm{R} \$ 1.600,00$ por família), a parcela do financiamento é de apenas $5 \%$ da renda mensal, porém, devido à restrição orçamentária, pode se tornar alta quando acrescentada a outras despesas.

Acrescenta-se a isso o fato de que os cenários econômico e político sofreram mudanças ao longo dos últimos anos, tornando-se menos favoráveis a investimentos e aumentando os níveis de endividamento e inadimplência, incluindo de financiamento habitacional. De acordo com estudos da Confederação Nacional do Comércio de Bens, Serviços e Turismo (CNC, 2016), o percentual de famílias brasileiras endividadas com financiamento de casa em janeiro de 2010 era de 3,1\%, passando, em dezembro de 2016, para 7,2\%. Observase que esse percentual indica apenas que mais famílias estão pagando financiamento da casa, entretanto, o percentual de inadimplência no PMCMV evidencia uma situação preocupante. Em relação aos níveis de inadimplência no PMCMV (atraso de mais de 90 dias no pagamento das parcelas) na Faixa 1, o atraso verificado no pagamento das mensalidades, em nível brasileiro, encontrava-se, em junho de 2015, em 23\% (Controladoria-Geral da União - CGU, 2016). Dessa forma, muitas famílias de baixa renda que tiveram acesso ao financiamento da casa própria, encontram grandes dificuldades para o pagamento das prestações. Explicando esse aumento do endividamento, ressalta-se a falta de planejamento e controle dos gastos (Santos \& Silva, 2014), como também o desemprego e a inexistência de uma reserva para incidentes e imprevistos, fazendo com que as famílias, na hora de pagarem suas dívidas, não tenham os recursos necessários para quitálas (Zerrenner, 2007).

Diante dessa situação, este artigo tem como objetivo geral apresentar um retrato da situação de inadimplência de beneficiários da Faixa I do Programa Minha Casa, Minha Vida. Como objetivos específicos têm-se: i) identificar o perfil dos entrevistados e as principais razões da inadimplência; ii) analisar as práticas de gerenciamento financeiro utilizadas e a percepção da atitude ao endividamento; iii) verificar as diferenças entre os inadimplentes e adimplentes do PMCMV, segundo as variáveis relativas à atitude ao endividamento e iv) analisar o grau de associação entre as variáveis socioeconômicas e de gerenciamento financeiro com a inadimplência na Faixa I do PMCMV. Para cumprimento desses objetivos, realizou-se um estudo no município de Santa Maria, no Rio Grande do Sul (RS), o qual conta atualmente com 1860 unidades habitacionais, distribuídas em quatro condomínios, financiadas pelo Programa Minha Casa Minha Vida (Faixa 1).

A pesquisa se insere, assim, no âmbito dos estudos a respeito de finanças comportamentais, mais especificamente gerenciamento financeiro e aspectos inerentes à inadimplência num programa social, com política de subsídio e financiamento habitacional a famílias de diferentes faixas de renda. Podem ser citadas pesquisas que tratam da inadimplência em políticas habitacionais anteriores ao PMCMV, como as realizadas por Sehn e Carlini Junior (2007), Merigo e Rockenbach (2004) e Lobler et al (2000). Portanto, como contribuição e inovação ao campo de estudos relacionados ao Programa Minha Casa Minha Vida, tem-se a 
discussão a respeito de um tema ainda pouco explorado no âmbito das análises sobre essa política pública: a inadimplência do público de interesse social.

Todavia, cabe registrar que existem pesquisas a respeito de questões relacionadas aos problemas estruturais de moradia, urbanização e agentes envolvidos (Krause, Balbim \& Neto, 2013; Moura, 2014; D’Amico, 2011; Rizek, Amore \& Camargo, 2014); evolução dos programas habitacionais brasileiros e os aspectos positivos e negativos do PMCMV (Ramos \& Noia, 2016; Cunha, 2012; Andrade, 2012); impactos econômicos e financeiros (Shimizu, 2010; Souza \& Mello, 2017); fundo garantidor de habitação popular (Guilhen \& Meireles, 2017); satisfação dos beneficiários (Moreira \& Silveira, 2015; Brasil, 2014; Cunha, 2012) e ainda, uma pesquisa sobre inadimplência habitacional direcionada à classe média emergente brasileira (Locatelli et al, 2015), a qual utilizou base de dados secundária, diferentemente da presente pesquisa.

A pesquisa justifica-se pelo fato de que muitas famílias estão encontrando dificuldades para quitar suas parcelas do financiamento habitacional e, assim, pretendemos investigar quais fatores causam o alto nível de inadimplência que pode contribuir para que os problemas encontrados possam ser discutidos e melhorados, visto que o programa não tem previsão de término e o prazo de financiamento é longo. Ainda, a importância de estudar a atitude ao endividamento se dá pelo fato de que pessoas em situações difusas, com contas atrasadas e indisponibilidade de caixa são mais propensas a problemas, tanto de ordem financeira, quanto psicossocial (Keese \& Schmitz, 2011; Plagnol, 2011).

\section{FUNDAMENTOS TEÓRICOS}

\subsection{Gerenciamento Financeiro}

A administração das finanças familiares é fundamental, já que envolve a definição de quais métodos de controle devem ser utilizados, quem é responsável pelos pagamentos e negociações dos gastos pessoais (Burgoyne \& Morison, 1997). Atentar-se para que seja realizada uma eficiente administração financeira torna-se ainda mais importante entre famílias mais pobres, uma vez que pela escassez de recursos são necessárias melhores habilidades no uso do dinheiro (Budescu \& Taylor, 2013).

Essas habilidades referem-se ao planejamento financeiro, elaboração de orçamentos, planos de poupança e investimentos estratégicos. Necessita-se equidade entre receitas e despesas, evitando gastos supérfluos em detrimento de despesas básicas (Campara, 2016). Tratando-se das dificuldades no gerenciamento da renda familiar, têm-se os altos reajustes nos preços em oposição ao reajuste salarial e os gastos desnecessários, que contribuem de forma significativa no final do mês (Silva et al, 2014). Considera-se ainda a dificuldade dos indivíduos, principalmente de baixa renda, em guardar montantes financeiros, o que é maximizado pelo fato de a renda dessas famílias ser sazonal, fruto da informalidade (Rêgo \& Pinzani, 2013).

Entre as ações para um melhor uso monetário, tem-se a gestão de caixa, uma importante ferramenta que possibilita o controle das entradas e saídas de dinheiro, facilitando a visualização das condições financeiras e estimulando a vivência dentro de suas condições, administrando seu dinheiro de forma eficiente e eficaz (Leal \& Nascimento, 2012). Gerir os recursos disponíveis de forma consciente propicia uma relação favorável com o cumprimento financeiro das necessidades (Plagnol, 2011), a qualidade das decisões financeiras particulares e o planejamento delas, que podem influenciar toda a economia e estão intimamente ligados a problemas como inadimplência, endividamento familiar e falta de capacidade de planejamento de longo prazo (Cenci, Pereira \& Barichello, 2015). 


\subsection{Atitude ao Endividamento}

O consumo satisfaz necessidades básicas ou supérfluas, no entanto, devido à busca incessante pela satisfação, além da facilidade de acesso ao crédito, muitos indivíduos gastam mais que seus recursos, resultando em endividamento, sobre-endividamento e inadimplência (Frade et al, 2008; Gathergood, 2012).

Conceituando endividamento, Marques e Frade (2004) relatam que é um saldo devedor assumido, que deve ser quitado em um período fixado, tornando-se uma responsabilidade financeira. Nem sempre o endividamento é ruim, uma vez que pode ser também encarado como estratégia do consumidor num contexto de crescimento econômico (Marques et al, 2000). Ele se torna um problema quando o indivíduo compromete sua renda mais que o disponível. Essa condição é denominada sobre-endividamento, a incapacidade de quitar dívidas contraídas (Frade et al, 2008; Marques e Frade, 2004).

O caso mais grave de dívida é a inadimplência, quando o indivíduo contrai um montante elevado e ultrapassa suas condições de pagamento, consequentemente, os prazos não são cumpridos (Olivato \& Souza, 2007). Quanto às causas do sobre-endividamento e inadimplência, evidencia-se a perda de emprego e renda, doença própria e/ou de familiares, morte do responsável pela maior parte da renda familiar, gravidez não programada, separação conjugal, fatos considerados inesperados. Há também a falta de planejamento financeiro, compras por impulso, excesso de parcelamento, uso descontrolado de crédito, além de empréstimo do nome, onde um amigo ou familiar retira empréstimo e/ou financiamento em seu nome para terceiros (Banco Central do Brasil - BACEN, 2014).

Destacam-se nas famílias brasileiras o uso do cartão de crédito, cheque especial ou pré-datado, crédito consignado ou crédito pessoal, carnês, financiamento de carro e financiamento de imóvel (Confederação Nacional do Comércio de Bens, Serviços e Turismo - CNC, 2015). Fatores macroeconômicos que afetam a economia de modo geral também influenciam, entre eles a taxa de juros, desemprego, rendimento médio do pessoal ocupado, inflação, volume de vendas do comércio e o índice geral de preços ao consumidor amplo (Linardi, 2008; Silva et al, 2012).

A literatura existente sobre endividamento traz diversas relações com variáveis socioeconômicas. Em relação ao gênero, têm-se duas concepções distintas: mulheres como mais propensas ao endividamento (Trindade, Righi \& Vieira, 2012; Carvalho \& Alves, 2010; Vieira et al, 2014) e outros os homens (Wang, Lu \& Malhotra, 2011; Muller, 2010). Justificando essas relações, Trindade, Righi e Vieira (2012) salientam que as mulheres são mais propensas ao endividamento pela predisposição à aquisição de carnês e compras com maior frequência. Já os homens costumam utilizar o crédito rotativo frequentemente (Wang, Lu \& Malhotra, 2011), cartão de crédito, empréstimo pessoal, empréstimo consignado, limite de cheque e limite da conta (Muller, 2010).

No que tange à faixa etária, Ponchio (2006) e Vieira, Flores e Campara (2015) observaram a existência de uma relação negativa entre idade e endividamento. Ratificando essas evidências, Worthy, Jonkman e BlinnPike (2010) destacam que jovens de 18 a 25 anos são mais predispostos a assumir riscos maiores e apresentar menor estabilidade financeira, explicando sua maior vulnerabilidade à dívida.

Ao avaliar a relação entre estado civil e endividamento, Gathergood (2012) e Vieira, Flores e Campara (2015) observaram que os indivíduos solteiros possuem maior propensão ao endividamento e possuem maiores níveis de sobre-endividamento. De encontro a esta perspectiva, Mendes-Da-Silva, Nakamura e Moraes (2012) destacam as pessoas casadas como as mais vulneráveis a estourar o limite do cartão de crédito e a pagar somente uma parcela da fatura, elevando o nível da dívida. Vieira et al (2014), ao investigar o endividamento na mesorregião central do Estado do Rio Grande do Sul, indicou que mulheres separadas ou viúvas são mais propensas a contrair dívidas, pelas despesas da casa e cuidados com filhos.

Quanto à variável referente ao número de dependentes, Keese (2012) evidencia que famílias com maior número de filhos e dependentes, principalmente crianças, contraem maiores dívidas. Da mesma forma, Silva (2011), Godwin (1990) e Lea, Webley e Walker (1995) destacam que um grande impulsionador dos 
problemas de altos níveis de endividamento nas famílias é o aumento de gastos com situações imprevisíveis, como doenças.

Em relação à escolaridade, Vieira, Flores e Campara (2015) verificaram que indivíduos com menores níveis de escolaridade possuem maior propensão ao endividamento. Por outro lado, quanto maior a instrução, maior a possibilidade de se endividar, dado o conhecimento das opções de crédito (Miotto, 2013). Outro fator diretamente relacionado a níveis de endividamento é a renda. Zerrenner (2007), Vieira et al (2014) e Vieira, Flores e Campara (2015) constatam que indivíduos de baixa renda (que recebem até 3 salários mínimos) apresentam níveis significativos de endividamento.

\section{PROGRAMA MINHA CASA MINHA VIDA E SUA RELAÇÃO COM A INADIMPLÊNCIA}

Em 25 de março de 2009 foi emitida a Medida Provisória $n^{\circ}$ 459/09, convertida na Lei $\mathrm{n}^{\circ} 11.977$, implantando o PMCMV, tornando este um marco da política habitacional, que estabelece parcerias entre Governo Federal, estados, municípios e iniciativa privada. Sua criação parte do pressuposto que o acesso à moradia regular é condição básica para todos indivíduos, podendo superar vulnerabilidades sociais e alcançar a efetiva inclusão social. Todavia, para que isso seja possível, torna-se essencial o acesso ao financiamento habitacional para estas famílias, que muitas vezes não têm capacidade de poupança, exigindo condições especiais e subsídios governamentais (Shimizu, 2010).

Assim, com o intuito de facilitar o acesso à aquisição da casa própria para indivíduos de diferentes classes de renda, foram criadas três faixas de financiamento com base em valores da renda mensal familiar. A Faixa 1, que conta com elevados subsídios para a aquisição de moradia para famílias com renda mensal de até $\mathrm{R} \$$ 1.600,00; a Faixa 2, a qual facilitou o financiamento por meio de subsídios diretos à demanda e através da redução de taxas de juros para famílias com renda mensal de até $\mathrm{R} \$ 3.275,00$, e a Faixa 3, que criou condições favoráveis de acesso ao imóvel para famílias com renda mensal de até $\mathrm{R} \$$ 5.000,00 (Brasil, 2014).

Para a Faixa 1, a indicação e a seleção das famílias são realizadas pelo município/governo do estado e não podem possuir imóvel e nem ter recebido anteriormente benefícios de natureza habitacional do Governo Federal. Devem estar cadastradas no Cadastro Único para Programas Sociais do Governo Federal. O prazo de amortização da dívida são 120 meses, onde o valor bruto da prestação corresponde ao valor do financiamento dividido por 120 e o valor líquido corresponde a $5 \%$ da renda bruta familiar mensal ou $\mathrm{R} \$ 25,00$, o que for maior, o restante é subsidiado pelo Programa (CEF, 2015a).

Salienta-se que em março de 2016 iniciou-se uma nova fase do PMCMV, com alterações referentes às faixas de renda, juros, subsídios e valores das prestações. Criou-se uma nova faixa de renda, a Faixa 1,5, e o valor limite de renda da Faixa 1 passou de $\mathrm{R} \$ 1.600,00$ para $\mathrm{R} \$ 1.800,00$ por família. As prestações da Faixa 1 continuarão a ser pagas em 10 anos, sendo que, para as famílias que recebem até $\mathrm{R} \$ 800$, a parcela será de $\mathrm{R}$ $\$ 80$; entre $\mathrm{R} \$ 800$ e $\mathrm{R} \$ 1.200$, o valor corresponderá a $10 \%$ da renda; de $\mathrm{R} \$ 1.200$ a $\mathrm{R} \$ 1.600$ pagará $15 \%$; e de $\mathrm{R} \$ 1.600$ a $\mathrm{R} \$ 1.800,20 \%$ (Portal Brasil, 2015). Contudo, devido ao fato de a mudança ser relativamente recente, optou-se por utilizar as faixas de financiamento anteriores.

Sobre a seleção dos candidatos, o Manual do PMCMV indica que o parâmetro para a seleção deve observar os seguintes critérios: famílias residentes em áreas de risco ou insalubres ou desabrigadas; famílias com mulheres responsáveis pela unidade familiar e famílias das quais façam parte pessoas com deficiência. É permitido às mulheres chefes de família firmar contrato de financiamento independente do cônjuge, além da participação de pessoas com restrição cadastral no Serviço de Proteção ao Crédito SPC e/ou SERASA (CEF, 2015a).

Quanto ao atraso no pagamento, a Caixa Econômica Federal realiza a cobrança das parcelas e, antes de qualquer ação definitiva, como a retomada do imóvel, esgotam-se as providências de orientação e cobranças administrativas. O objetivo do Governo Federal não é retomar os imóveis inadimplentes, mas sim ajudar os beneficiários a superar dificuldades (Santiago, 2015). Reiterando essa afirmação, tem-se que uma das 
diretrizes do PMCMV é a execução de trabalho social "entendido como um conjunto de ações inclusivas, de caráter socioeducativo, voltadas para o fortalecimento da autonomia das famílias, sua inclusão produtiva e a participação cidadã, contribuindo para a sustentabilidade dos empreendimentos habitacionais”. Mencionase ainda, no eixo "Planejamento e Gestão do Orçamento Familiar", a prática de "divulgação de informações sobre organização e planejamento do orçamento familiar, e sobre a racionalização dos gastos com moradia; e orientação às famílias sobre as tarifas sociais dos serviços públicos" (Portaria n ${ }^{\circ} 168$, de 12 de abril de 2013).

Tratando-se do endividamento e inadimplência no PMCMV (Faixa 1), de acordo com os dados disponibilizados pelo Ministério da Transparência e Controladoria Geral da União (CGU, 2016), o atraso no pagamento (mais de 90 dias) do financiamento habitacional encontrava-se, em primeiro de julho de 2015, em 22\% (CGU, 2016). Observa-se, assim, que quase um em cada cinco beneficiários da Faixa 1 possuía pelo menos uma prestação vencida há mais de três meses.

Avaliando os motivos que levariam à inadimplência na Faixa 1, o estudo encontrado com maior similaridade com a presente pesquisa foi realizado por Locatelli et al (2015), o qual teve por objetivo identificar os determinantes de inadimplência em operações de crédito habitacional com o emprego do modelo de regressão logística. Para tanto, os autores utilizaram dados cadastrais de mutuários de operações de crédito habitacional de uma grande instituição financeira brasileira, tendo a pesquisa contemplado 37.521 mutuários com faixa salarial entre $\mathrm{R} \$ 300,00$ e $\mathrm{R} \$ 1.000,00$ mensais. Foi verificado que a probabilidade de inadimplência aumenta com a idade do tomador de empréstimo, sendo maior para os mutuários masculinos, casados e para os de maior escolaridade.

Estudos anteriores à implantação do PMCMV, realizados com devedores dos contratos de financiamento habitacional, foram desenvolvidos por Lobler et al (2000), Sehn e Carlini Junior (2007) e Merigo e Rockenbach (2004). Lobler et al (2000) utilizaram como objeto de pesquisa a Caixa Econômica Federal (CEF) por ser órgão de referência em termos de fomento a financiamentos habitacionais. A população foram todos os mutuários inadimplentes com atraso nas prestações superior a 60 dias, em Santa Maria (RS). Evidenciou-se que a falta de conhecimento por parte do mutuário de algumas cláusulas básicas relativas ao financiamento, a falta de eficiência de cobrança por parte da CEF e a diminuição na renda foram os fatores causadores da inadimplência.

Sehn e Carlini Junior (2007), com o objetivo compreender o grau de importância dado pelos mutuários da CEF no que se refere à inadimplência habitacional, aplicaram questionários a mutuários inadimplentes em Pernambuco. Os resultados indicaram a perda de renda, descontrole financeiro, doença na família e desemprego como fatores que mais causaram inadimplência. Muitos mutuários tiveram perda de renda ou comprometeram um porcentual muito grande de sua renda, dificultando os pagamentos atuais e futuros. Outra questão evidenciada foi que, para os entrevistados, a saúde está em primeiro lugar nas suas prioridades, em seguida vêm habitação e educação, assim, a habitação não está entre as prioridades quando o orçamento diminui.

Contextualizando a política habitacional, também anterior ao PMCMV, Merigo e Rockenbach (2004) verificaram o motivo da inadimplência das famílias que adquirem habitações por meio do poder público no município de Restinga Sêca (RS). A partir das entrevistas realizadas, concluiu-se que os fatores relevantes para a inadimplência foram baixa renda familiar, falta de conscientização em relação ao Programa e desconhecimento da política habitacional adotada pelo município.

Retomando a inadimplência no PMCMV, cita-se Brandão (2014), vice-presidente de Habitação Econômica do Sindicato das Empresas de Compra, Venda, Locação e Administração de Imóveis Residenciais e Comerciais de São Paulo, o qual relata que o valor pago pelas famílias é baixo, tendo uma relação de propriedade menos efetiva, o que pode tornar-se um motivo para uma menor preocupação com o pagamento da habitação. No mesmo sentido, Lauro Gonzales, coordenador do centro de estudos em micro finanças e inclusão financeira da Fundação Getúlio Vargas (FGV), em reportagem de Cucolo (2015), relata que em um financiamento, quando é cobrada uma prestação de valor muito inferior à capacidade de pagamento, ela 
acaba tendo menor importância. Além disso, Gonzales afirma que o cenário econômico também favorece a inadimplência, devido à perda de renda, em função do aumento do desemprego e inflação.

Outro fator relevante é que ainda não foram retomados imóveis na Faixa 1 pela inadimplência. Nas Faixas 2 e 3 já foram retomadas mais de cinco mil moradias (Cucolo, 2015). Brandão (2014) afirma que as condições acabam sendo demasiadamente favoráveis para o não pagamento do parcelamento do imóvel e que seria importante uma investigação mais precisa das condições financeiras das famílias. A Caixa estuda maneiras de atuar para diminuir a inadimplência no programa e sugere que possíveis mudanças incluam maior rigidez na seleção dos beneficiários, exigindo pagamento de entrada e ações educacionais (Associação Brasileira de Cohabs e Agentes Públicos de Habitação, 2016).

\section{MÉTODO}

\subsection{Local de estudo e instrumento de pesquisa}

Considerando a população de 1860 beneficiários da Faixa 1 do MCMV na cidade de Santa Maria (RS), residentes nos condomínios Videiras, Dom Ivo e Zilda Arns (segundo dados do Portal Brasileiro de Dados Abertos, 2015), foi adotado o processo de amostragem, que permite selecionar um número adequado de indivíduos de modo que se possam fazer generalizações de forma confiável (Mattar, 2005). Martins (2011) apresenta uma alternativa para a estimação de amostras, a qual é apresentada na Equação 1.
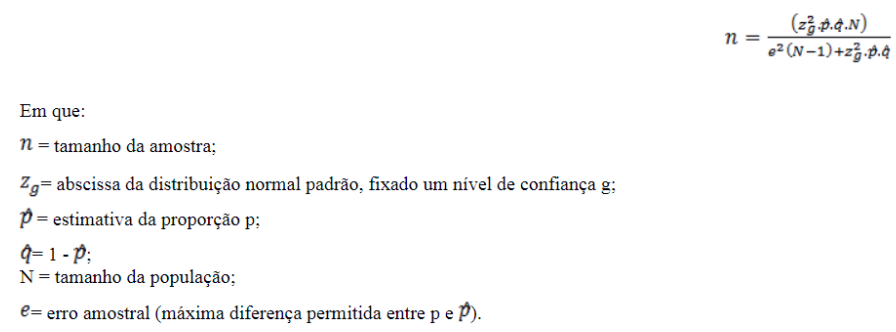

Assim, considerando um nível de confiança de $95 \%$ e um erro amostral de 8,0\%, obteve-se uma amostra mínima de 148 casos. No entanto, a amostra final foi ligeiramente superior a esse número e compreendeu 155 beneficiários. A amostra foi estratificada pelos condomínios existentes e em cada condomínio foram escolhidas aleatoriamente as moradias a serem entrevistados os responsáveis pelo financiamento através do programa. Como instrumento de coleta, utilizou-se um questionário com 4 blocos de questóes. No primeiro bloco, foi investigado se o beneficiário tem/já teve ou não o pagamento de prestações do financiamento habitacional atrasadas. No caso de estar com prestações atrasadas ou já ter atrasado em algum momento, foi perguntando o principal motivo.

O segundo bloco, denominado gerenciamento financeiro, refere-se à gestão, decisões, práticas e experiências financeiras dos indivíduos. O intuito desses questionamentos foi identificar como é a relação dos beneficiários do PMCMV com os recursos monetários. Para tanto, elencou-se 10 questões: se os beneficiários possuem dívidas, dívidas em atraso, cartão de crédito, carnês de lojas; se estão dentro do orçamento mensal; qual a situação financeira que se encontram; se conseguem fazer controle dos gastos e conseguem economizar. Questionou-se também se o indivíduo já teve o nome vinculado a algum cadastro negativo de dívida e se empresta ou já emprestou o nome para alguém realizar uma compra. A estruturação dessas questões se deu a partir da adaptação de modelos já aplicados por Shockey (2002), pelo Ministério do Desenvolvimento Social e Combate à Fome; Secretaria de Avaliação e Gestão da Informação (2014) e por Flores (2012).

O terceiro bloco buscou avaliar o nível de atitude ao endividamento dos beneficiários, através da escala desenvolvida originalmente por Lea, Webley e Walker (1995), e validada no Brasil por Moura (2005), 
composta por nove questões, as quais buscam identificar como os indivíduos se comportam com o uso do dinheiro, como planejam suas aquisições, suas opiniões sobre o consumo a prazo e a probabilidade de executarem tarefas que possam torná-los mais propensos ao consumo, sendo a escala utilizada do tipo likert de cinco pontos. Nesse sentido, se a pessoa respondesse um, representava ser menos propensa ao endividamento; se marcasse cinco teria uma tendência maior de acumular níveis elevados de dívida. Ressalta-se a existência de questóes invertidas, as quais passaram por uma reversão da escala para que ficassem com o mesmo processo interpretativo que as demais alternativas.

Por fim, foram elencadas questões referentes ao perfil dos respondentes, as quais visam caracterizar os indivíduos entrevistados. As variáveis inerentes a esse bloco são: idade, gênero, estado civil, número de dependentes, nível de escolaridade e qual o total da renda mensal familiar. Para a realização da coleta de dados, foram capacitados 5 pesquisadores que aplicaram o instrumento ao longo dos meses de abril e maio de 2016. Os questionários foram aplicados face a face com os entrevistados, através de visitas domiciliares.

4.2 Procedimentos Analíticos

Para a análise dos dados utilizou-se estatísticas descritivas, teste de diferença de média, análise de confiabilidade e testes de hipóteses de associação entre variáveis. Para as análises, foi criada uma variável binária com valor zero (0) para indivíduos classificados como adimplentes no PMCMV e valor um (1) para indivíduos inadimplentes no mesmo programa. As variáveis socioeconômicas selecionadas com base no referencial teórico são apresentadas no Quadro 01. 
Quadro 01- Variáveis socioeconômicas e de gerenciamento financeiro e suas respectivas dummies ou rótulos.

\begin{tabular}{|c|c|c|}
\hline Bloco & Variável & Dummy ou Rótulo \\
\hline \multirow{6}{*}{ Socioeconômico } & Gênero & Masculino (0); Feminino (1). \\
\hline & Estado Civil & $\begin{array}{l}\text { Casado (0); } \\
\text { Solteiro/viúvo/separado } \\
\text { (1). }\end{array}$ \\
\hline & Dependentes & $\begin{array}{l}\text { Não possui dependente (0); } \\
\text { Possui dependente (1). }\end{array}$ \\
\hline & Idade & $\begin{array}{l}\text { Até } 31 \text { anos (1); De } 32 \text { a } 41 \\
\text { anos (2); De } 42 \text { a } 55 \text { anos } \\
\text { (3); Acima de } 55 \text { anos (4). }\end{array}$ \\
\hline & Escolaridade & $\begin{array}{l}\text { Nunca estudei, Ensino } \\
\text { Fundamental de } 1^{a} \text { a } 4^{a} \\
\text { série, Ensino Fundamental } \\
\text { de } 5^{a} \text { a } 9^{a} \text { série e Ensino } \\
\text { Médio (1); Curso Técnico, } \\
\text { Faculdade (Ensino } \\
\text { Superior), Especialização } \\
\text { ou MBA e } \\
\text { mestrado/doutorado/ } \\
\text { pós-doutorado (2); }\end{array}$ \\
\hline & $\begin{array}{l}\text { Renda } \\
\text { mensal } \\
\text { familiar }\end{array}$ & $\begin{array}{l}\text { Até } \mathrm{R} \$ 980,00 \text { (1); Entre } \\
\mathrm{R} \$ 980,01 \text { e } \mathrm{R} \$ 1.400,00 \\
\text { (2); Entre } \mathrm{R} \$ 1.400,01 \text { e } \mathrm{R} \$ \\
2.000,00 \text { (3); Acima de } \mathrm{R} \$ \\
2.000,00 \text { (4). }\end{array}$ \\
\hline \multirow{10}{*}{$\begin{array}{l}\text { Gerenciamento } \\
\text { Financeiro }\end{array}$} & Dívidas & $\begin{array}{l}\text { Não possui dividas (0); } \\
\text { Possui dividas (1). }\end{array}$ \\
\hline & $\begin{array}{l}\text { Dividas em } \\
\text { atraso }\end{array}$ & $\begin{array}{l}\text { Não possui dividas em } \\
\text { atraso (0); Possui dividas } \\
\text { em atraso (1). }\end{array}$ \\
\hline & $\begin{array}{l}\text { Possuir } \\
\text { Cartão de } \\
\text { Crédito }\end{array}$ & $\begin{array}{l}\text { Não possui cartão de } \\
\text { crédito (0); Possui cartão de } \\
\text { crédito (1). }\end{array}$ \\
\hline & $\begin{array}{l}\text { Possuir } \\
\text { Carnê de } \\
\text { Crediário }\end{array}$ & $\begin{array}{l}\text { Não possui carnê de } \\
\text { crediário (0); Possui carnê } \\
\text { de crediário (1). }\end{array}$ \\
\hline & Gastos & $\begin{array}{l}\text { Gasta menos ou igual ao } \\
\text { que ganha (0); Gasta mais } \\
\text { que ganha (1). }\end{array}$ \\
\hline & $\begin{array}{l}\text { Situação do } \\
\text { Dinheiro }\end{array}$ & $\begin{array}{l}\text { Pagam todas as contas } \\
\text { mensais (0); Geralmente } \\
\text { não conseguem pagar } \\
\text { todas as contas mensais } \\
\text { (1). }\end{array}$ \\
\hline & $\begin{array}{l}\text { Controle dos } \\
\text { Gastos }\end{array}$ & $\begin{array}{l}\text { Mantém algum controle } \\
\text { sobre os gastos (0); Não } \\
\text { controla os gastos(1). }\end{array}$ \\
\hline & Poupança & $\begin{array}{l}\text { Já fez no passado ou está } \\
\text { fazendo(0); Nunca fez (1). }\end{array}$ \\
\hline & $\begin{array}{l}\text { Nome ligado } \\
\text { ao Cadastro } \\
\text { Negativo }\end{array}$ & $\begin{array}{l}\text { Nunca teve o nome ligado } \\
\text { ao cadastro negativo (0); Já } \\
\text { teve ou está com o nome } \\
\text { ligado ao cadastro negativo } \\
\text { (1). }\end{array}$ \\
\hline & $\begin{array}{l}\text { Empréstimo } \\
\text { do nome }\end{array}$ & $\begin{array}{l}\text { Nunca emprestou o nome } \\
\text { para alguém realizar } \\
\text { alguma compra (0); Já } \\
\text { emprestou ou está } \\
\text { emprestando (1). }\end{array}$ \\
\hline
\end{tabular}

Fonte: Elaborada pelas autoras. 
Inicialmente realizou-se uma análise descritiva do percentual de adimplentes e inadimplentes do Programa e, descrito o perfil, o gerenciamento financeiro e a atitude ao endividamento dos entrevistados segundo os dois grupos. Apresentou-se ainda a média em cada variável pertencente à atitude ao endividamento para ambos os grupos e, a fim de verificar se existem diferenças de atitude ao endividamento entre os adimplentes e inadimplentes, foi realizado o teste de diferença de média, Teste t de Student, o qual compara a média de uma variável em um grupo com a média da mesma variável em outro grupo. Ressalta-se que, para avaliar o nível de confiabilidade da atitude ao endividamento, utilizou-se o Alfa de Cronbach, o qual verifica a consistência interna de uma escala agregada com base na correlação média entre os pares de indicadores. Índices de confiabilidade superiores a 0,7 têm sido considerados satisfatórios para pesquisas em geral. Já para pesquisas de natureza exploratória, valores superiores a 0,6 têm sido considerados aceitáveis (HAIR et al, 2010).

Posteriormente, foi analisada a associação entre as variáveis socioeconômicas e de gerenciamento financeiro com a adimplência e inadimplência no PMCMV. Para tanto, foi construída uma tabela de contingência das variáveis adimplência e inadimplência no PMCMV para cada valor das variáveis explicativas com escala nominal ou ordinal. Além disso, calculou-se a medida de associação Qui-Quadrado de Pearson entre cada par: variável explicativa $\mathrm{x}$ adimplência e inadimplência no PMCMV. A hipótese nula do teste é de que as variáveis são independentes e a hipótese alternativa é que existe relação entre as variáveis. Se as diferenças entre os valores observados não são estatisticamente diferentes (sig $>0,05)$, as variáveis são independentes, caso contrário, rejeita-se a hipótese nula de independência. Contudo, o teste do QuiQuadrado apenas informa sobre a independência entre as variáveis, mas nada diz sobre o grau de associação existente (Pestana \& Gageiro, 2008).

A fim de medir o grau de associação entre as variáveis, foram apresentadas medidas de associação baseadas nas estatísticas do Qui-Quadrado, sendo estas Fi e o V de Cramer, medidas do grau de associação entre duas variáveis categóricas. O Fi é utilizado com tabelas de contigência $2 \times 2$ (tabelas que possuem variáveis categóricas e cada variável tem somente duas categorias). O V de Cramer é mais adequado se uma das duas variáveis categóricas apresenta mais de duas categorias (Field, 2009). As medidas de associação normalmente variam entre zero e um, isto é, desde ausência da relação até a relação perfeita entre as variáveis. Os valores baixos indicam uma pequena associação entre variáveis, enquanto que os valores elevados indicam uma grande associação entre as variáveis (Pestana \& Gageiro, 2008).

\section{RESULTADOS E DISCUSSÕES}

\subsection{Perfil dos entrevistados e principais razóes da inadimplência}

Em relação ao perfil dos entrevistados, segundo as variáveis socioeconômicas, verificou-se que, entre os adimplentes no PMCMV, 78,57\% são mulheres, com 42 anos ou mais $(68,57 \%)$, casadas $(51,43 \%)$, que possuem dependentes (62,86\%), com escolaridade entre Ensino Fundamental e Ensino Médio (86,76\%) e rendas heterogêneas, sendo que $80 \%$ possui renda familiar de até $\mathrm{R} \$ 2.000,00$ mensais. Quanto aos inadimplentes, observou-se que a maioria é mulher (88,24\%), com até 41 anos (68,24\%), casadas (51,76\%) ou solteiras $(31,76 \%)$, que possuem dependentes $(79,01 \%)$, com escolaridade entre Ensino Fundamental e Ensino Médio (96,43\%), sendo a maioria (51,76\%) com renda familiar mensal de até R\$1.400,00. Na Tabela 1 é apresentada a estatística descritiva dos adimplentes e inadimplentes no PMCMV, e referente aos inadimplentes, o principal motivo que os levou a atrasar o pagamento das parcelas. 
Tabela 01 - Percentual de adimplentes e inadimplentes do PMCMV e motivo principal pelo atraso das prestações.

\begin{tabular}{|c|c|c|c|}
\hline Variável & Alternativas & Percentual & $\begin{array}{l}\text { Percentual } \\
\text { Acumulado }\end{array}$ \\
\hline \multirow{3}{*}{$\begin{array}{l}\text { Você teve } \\
\text { ou tem } \\
\text { prestações } \\
\text { da casa } \\
\text { atrasadas? }\end{array}$} & Não, nunca teve. & 45,16 & 45,16 \\
\hline & $\begin{array}{l}\text { Nẫo tem no momento, } \\
\text { mas já teve no } \\
\text { passado. }\end{array}$ & 34,84 & 80,00 \\
\hline & $\begin{array}{l}\text { Sim, está com } \\
\text { prestações em atraso. }\end{array}$ & 20,00 & 100,00 \\
\hline \multirow{5}{*}{$\begin{array}{l}\text { Se você já } \\
\text { teve ou } \\
\text { tem } \\
\text { prestações } \\
\text { do PMCMV } \\
\text { em atraso, } \\
\text { qual foi (é) } \\
\text { o motivo } \\
\text { principal? }\end{array}$} & $\begin{array}{l}\text { Usou o dinheiro em } \\
\text { despesas inesperadas } \\
\text { (exemplo: doença, } \\
\text { desemprego). }\end{array}$ & 38,37 & 38,37 \\
\hline & Outro. & 25,58 & 63,95 \\
\hline & $\begin{array}{l}\text { Optou por pagar } \\
\text { outras contas maiores } \\
\text { e mais urgentes. }\end{array}$ & 17,44 & 81,39 \\
\hline & Nẫo sobrou dinheiro. & 13,96 & 95,35 \\
\hline & $\begin{array}{l}\text { Não se preocupou em } \\
\text { pagar, pois acredita } \\
\text { que não vai perder a } \\
\text { casa se não quitar a } \\
\text { prestação. }\end{array}$ & 4,65 & 100,00 \\
\hline
\end{tabular}

A maioria dos entrevistados $(54,84 \%)$ já teve no passado ou está com prestações da casa atrasadas. O percentual de indivíduos com prestações em atraso no momento da pesquisa foi de $20 \%$. Ao serem questionados sobre o principal motivo para o não pagamento das prestações, 38,37\% dos entrevistados afirmaram que o dinheiro foi utilizado em despesas inesperadas, em função de doença ou desemprego e $25,58 \%$, que o motivo foi outro, onde foi destacado o atraso no envio do boleto de pagamento, esquecimento e ainda falecimento de algum familiar. Esses resultados ratificam o que foi encontrado por Lobler et al (2000) e Sehn e Carlini Junior (2007) ao pesquisarem a inadimplência em financiamentos habitacionais anteriores ao PMCMV, em Santa Maria (RS) e em cidades do estado de Pernambuco (PE), respectivamente, o que evidencia a falta de eficiência de cobrança por parte da CEF, a diminuição na renda, descontrole financeiro, doença na família e desemprego como fatores que causam a inadimplência.

Salienta-se também que o agravamento da crise se tornou um fator relevante para o não pagamento das prestações, dado que aumentou o nível de desemprego e diminuiu a renda de muitas famílias brasileiras. Esses resultados vão ao encontro do que é descrito por Lauro Gonzales, que afirma que o cenário econômico também favorece a inadimplência no PMCMV, devido à perda de renda, em função do aumento do desemprego e inflação. Linardi (2008) e Silva et al (2012) também elencam como algumas das causas do endividamento e inadimplência em diferentes setores da economia o desemprego e inflação. Quanto ao atraso por acreditar que não perderá a casa se não quitar a prestação, o qual foi destacado por Cucolo (2015) e a Associação Brasileira de Cohabs e Agentes Públicos de Habitação (2016) como um dos motivos pelo alto percentual de inadimplentes na Faixa 1, o percentual foi pequeno (4,65\%), demonstrando que este não é um dos principais motivos pelo atraso no pagamento, na perspectiva dos respondentes desta pesquisa.

\subsection{Práticas de gerenciamento financeiro utilizadas e a percepção da atitude ao endividamento}

Analisando características pertinentes ao gerenciamento financeiro dos indivíduos adimplentes no PMCMV, tem-se que menos da metade não possui dívidas $(42,86 \%)$ e entre os que possuem, $45,71 \%$ afirmaram que devem em lojas de crediário próprio e $27,14 \%$, em algum banco ou financeira. Contudo, a 
maioria relatou que não possui dívidas em atraso (78,57\%). Referente a possuir ou não cartão de crédito e carnê de crediário, 44,29\% relatou não possuir nenhum. Com relação aos gastos, $75,72 \%$ dos adimplentes gastam menos ou igual ao que ganham e $24,29 \%$ gastam mais do que ganham. Tratando-se da situação do dinheiro que a família ganha a cada mês, 90\% afirmaram conseguir pagar as despesas mensais, contudo, $31,43 \%$ salientam que periodicamente sobra pouco para comprar coisas extras e $38,57 \%$, que não conseguem comprar coisas extras.

Quanto ao controle dos gastos, $91,43 \%$ dos adimplentes afirmam manter pelo menos um pequeno controle sobre os gastos, contudo, apenas $20 \%$ utilizam anotações por escrito. Referente à poupança, $47,14 \%$ relatam nunca ter feito poupança e 31,43\% tem poupança em dinheiro no banco. Perguntados se têm ou tiveram seu nome ligado ao cadastro negativo, 34,29\% afirmam nunca ter tido o nome "sujo na praça" e 41,43\% já teve no passado. Ainda, $50 \%$ nunca emprestou o nome para outra pessoa realizar compras, enquanto $42,86 \%$ estão emprestando.

Consegue-se verificar assim uma relação entre esses resultados e o que já foi evidenciado na literatura, como ações positivas para um bom gerenciamento financeiro. Foi visto que a maioria dos indivíduos adimplentes não possuem dívidas em atraso e gastam menos ou igual ao que ganham, ratificando o estudo de Campara (2016) que observou que é necessário equidade entre receitas e despesas, tendo as famílias que analisar quais suas fontes de renda e suas prioridades. Em relação ao controle financeiro, Braido (2014) destaca que este é um grande aliado na busca por uma gestão coerente dos recursos e foi visto que, entre os adimplentes, 91,43\% afirmam manter pelo menos um pequeno controle sobre os gastos. Quanto ao ato de poupar, destacado por Canova, Rattazzi e Webley (2005) como muito importante no gerenciamento financeiro, a maioria dos adimplentes já fez ou está fazendo poupança.

Traçando o perfil dos inadimplentes no PMCMV, apenas 27,06\% não têm outras dívidas além do financiamento da casa e 42,35\% não têm dívidas em atraso, sendo que, quanto às dívidas em atraso, 32,94\% as possuem com lojas de crediário próprio e $24,71 \%$, com banco ou financeira. A maioria não possui cartão de crédito (58,82\%), já quanto a carnês de crediário, 52,43\% afirmou que ele mesmo e/ou outra pessoa moradora da casa possui. Quanto aos gastos, 53,57\% dos inadimplentes gasta menos ou igual ao que ganha e 46,43\% gasta mais que ganha. Tratando-se da situação do dinheiro que a família ganha a cada mês, 38,10\% afirmaram não conseguir pagar todas as despesas mensais e 29,76\% pagam as despesas, mas não conseguem comprar coisas extras. Menos de 10\% geralmente tem mais do que precisam e conseguem economizar ou comprar coisas extras.

Em relação ao controle dos gastos, 87,05\% afirmam manter pelo menos um pequeno controle sobre os gastos e 32,94\% utilizam anotações por escrito. Referente à poupança, 58,82\% nunca fizeram poupança, e 22,35\% não estão fazendo, mas já fizeram algum dia. Apenas 8,24\% nunca tiveram seu nome ligado ao cadastro negativo e $60,00 \%$ estão com o "nome sujo" atualmente. A maioria (58,82\%) já emprestou ou está emprestando o nome para outra pessoa realizar alguma compra. Dentre esses resultados, destacam-se alguns fatos, como os inadimplentes possuírem bem mais dívidas e dívidas em atraso que os adimplentes, sendo a maioria dessas dívidas com lojas ou bancos, ou de ordem financeira. Mostrou-se ainda que um maior percentual de inadimplentes em relação aos adimplentes não possui cartão de crédito e carnê de loja e ainda, o percentual de inadimplentes que gasta mais do que ganha é $22,14 \%$ maior do que o de adimplentes e os que não conseguem pagar todas as despesas mensais é $28,10 \%$ maior.

Observou-se ainda que o percentual de inadimplentes que nunca fez poupança é 11,68\% maior que os adimplentes. Outro destaque é que apenas $8,24 \%$ dos inadimplentes nunca tiveram o nome ligado ao cadastro negativo, percentual 26,05\% menor que o de adimplentes. Ademais, o percentual de inadimplentes com "nome sujo" atualmente é mais que o dobro do de adimplentes. Verifica-se com esses resultados que os indivíduos inadimplentes no PMCMV atrasam não só o pagamento das prestações da casa, mas também outras dívidas, e muitos deles têm o nome ligado ao Cadastro Negativo, o que explica o fato de não terem cartão de crédito e carnê de loja. Evidenciou-se que os beneficiários inadimplentes tendem a ter 
comportamentos financeiros mais inadequados que os adimplentes, como o hábito de terem mais dívidas, gastarem mais do que ganham, controlar menos os gastos e poupar menos, além de emprestar o nome para outras pessoas realizarem compras.

Essas características de gerenciamento financeiro corroboram com o que foi descrito pelo Banco Central do Brasil (2014) como principais causas do endividamento excessivo e inadimplência. Destacando a falta de planejamento financeiro, levando a ocorrências de excesso de parcelamento de compras e uso de linhas de crédito impulsivamente, além de empréstimo do nome. Torna-se claro que a situação financeira dos inadimplentes passa por mais problemas do que a dos adimplentes, seja pela falta de recursos, por desemprego, pela falta de organização e, como foi visto, por práticas de gerenciamento financeiro menos adequadas. Com $\mathrm{o}$ intuito de se aprofundar nas questões relativas ao comportamento dos beneficiários foi analisada a atitude ao endividamento dos respondentes (Tabelas 2 e 3 ). Constata-se que as nove questões apresentadas na Tabela 02 compóem o construto Atitude ao Endividamento, o qual apresentou Alfa de Cronbach de 0,6, o que demonstra sua confiabilidade.

Tabela 2 - Percentuais de discordância, indiferença e concordância das variáveis de Atitude ao Endividamento, conforme os Adimplentes (Adim) e Inadimplentes (Inad) do PMCMV

\begin{tabular}{|c|c|c|c|c|c|c|c|c|c|c|}
\hline \multirow{3}{*}{ Variáveis } & \multicolumn{10}{|c|}{ Percentuais } \\
\hline & \multicolumn{2}{|c|}{$\begin{array}{l}\text { Discordo } \\
\text { totalmente }\end{array}$} & \multicolumn{2}{|c|}{ Discordo } & \multicolumn{2}{|c|}{ Indiferente } & \multicolumn{2}{|c|}{ Concordo } & \multicolumn{2}{|c|}{$\begin{array}{l}\text { Concordo } \\
\text { Totalmente }\end{array}$} \\
\hline & Adim & Inad & Adim & Inad & Adim & Inad & Adim & Inad & Adim & Inad \\
\hline $\begin{array}{l}\text { Para você, é normal as } \\
\text { pessoas ficarem } \\
\text { endividadas para } \\
\text { pagar suas contas. }\end{array}$ & 34,78 & 19,28 & 34,78 & 27,71 & 1,45 & 1,20 & 24,64 & 31,33 & 4,35 & 20,48 \\
\hline $\begin{array}{l}\text { Năo é certo gastar mais } \\
\text { do que você ganha. }\end{array}$ & 5,97 & 2,47 & 1,49 & 1,23 & 0,00 & 0,00 & 26,87 & 22,22 & 65,67 & 74,07 \\
\hline $\begin{array}{l}\text { As pessoas ficariam } \\
\text { desapontadas contigo } \\
\text { se soubessem que você } \\
\text { tem divida. }\end{array}$ & 5,80 & 21,43 & 17,39 & 15,48 & 27,54 & 21,43 & 23,19 & 23,81 & 26,09 & 17,86 \\
\hline $\begin{array}{l}\text { Você prefere comprar } \\
\text { parcelado do que } \\
\text { esperar ter dinheiro } \\
\text { para comprar à vista. }\end{array}$ & 39,13 & 26,19 & 26,09 & 27,38 & 1,45 & 1,19 & 27,54 & 34,52 & 5,80 & 10,71 \\
\hline $\begin{array}{l}\text { Você prefere pagar } \\
\text { parcelado mesmo que } \\
\text { no total saia mais caro. }\end{array}$ & 43,48 & 33,33 & 36,23 & 29,76 & 2,90 & 1,19 & 15,94 & 27,38 & 1,45 & 8,33 \\
\hline $\begin{array}{l}\text { É melhor primeiro } \\
\text { juntar dinheiro e só } \\
\text { depois gastar. }\end{array}$ & 4,35 & 12,20 & 7,25 & 12,20 & 2,90 & 2,44 & 43,48 & 34,15 & 42,03 & 39,02 \\
\hline $\begin{array}{l}\text { Não tem problema ter } \\
\text { divida se você sabe que } \\
\text { pode pagar. }\end{array}$ & 2,90 & 9,52 & 14,49 & 13,10 & 0,00 & 1,19 & 65,22 & 46,43 & 17,39 & 29,76 \\
\hline $\begin{array}{l}\text { Você sabe exatamente } \\
\text { quanto deve em lojas, } \\
\text { cartão de crédito ou } \\
\text { banco. }\end{array}$ & 4,35 & 16,67 & 17,39 & 15,48 & 4,35 & 2,38 & 33,33 & 29,76 & 40,58 & 35,71 \\
\hline $\begin{array}{l}\text { É importante saber } \\
\text { controlar os gastos da } \\
\text { sua casa. }\end{array}$ & 0,00 & 0,00 & 0,00 & 0,00 & 0,00 & 0,00 & 35,71 & 29,27 & 64,29 & 70,73 \\
\hline
\end{tabular}


Luana dos Santos Fraga, et al. Retrato da inadimplência dos beneficiários da Faixa 1 do "Minha Cas...

Tabela 03-Estatística Descritiva e Teste $t$ de diferenças de média, da Atitude ao Endividamento, conforme Adimplentes e Inadimplentes do PMCMV

\begin{tabular}{|c|c|c|c|c|c|}
\hline \multirow[b]{2}{*}{ Variáveis } & \multicolumn{2}{|l|}{ Média } & \multicolumn{3}{|c|}{ Teste T } \\
\hline & Adimplentes & Inadimplentes & Valor & Sig. & $\begin{array}{l}\text { Diferença } \\
\text { de } \\
\text { Média }\end{array}$ \\
\hline $\begin{array}{l}\text { Para você, é } \\
\text { normal as } \\
\text { pessoas } \\
\text { ficarem } \\
\text { endividadas } \\
\text { para pagar } \\
\text { suas contas. }\end{array}$ & 2,29 & 3,06 & $-3,42$ & $0,00^{* * *}$ & 0,77 \\
\hline $\begin{array}{l}\text { Não é certo } \\
\text { gastar mais do } \\
\text { que você } \\
\text { ganha. * }\end{array}$ & 1,55 & 1,36 & 1,30 & 0,20 & $\begin{array}{l}0,19 \\
\text { (NS) }\end{array}$ \\
\hline $\begin{array}{l}\text { As pessoas } \\
\text { ficariam } \\
\text { desapontadas } \\
\text { contigo se } \\
\text { soubessem } \\
\text { que você tem } \\
\text { divida. * }\end{array}$ & 2,54 & 2,99 & $-2,10$ & $0,04^{* *}$ & 0,45 \\
\hline $\begin{array}{l}\text { Você prefere } \\
\text { comprar } \\
\text { parcelado do } \\
\text { que esperar ter } \\
\text { dinheiro para } \\
\text { comprar à } \\
\text { vista. } \\
\end{array}$ & 2,35 & 2,76 & $-1,80$ & $0,07^{*}$ & 0,41 \\
\hline $\begin{array}{l}\text { Você prefere } \\
\text { pagar } \\
\text { parcelado } \\
\text { mesmo que no } \\
\text { total saia mais } \\
\text { caro. }\end{array}$ & 1,96 & 2,48 & $-2,54$ & $0,01 * * *$ & 0,52 \\
\hline $\begin{array}{l}\text { É melhor } \\
\text { primeiro } \\
\text { juntar } \\
\text { dinheiro e só } \\
\text { depois gastar. * }\end{array}$ & 1,88 & 2,24 & $-1,79$ & $0,08^{*}$ & 0,36 \\
\hline $\begin{array}{l}\text { Não tem } \\
\text { problema ter } \\
\text { divida se você } \\
\text { sabe que pode } \\
\text { pagar. }\end{array}$ & 3,80 & 3,74 & 0,32 & 0,75 & 0,06 (NS) \\
\hline $\begin{array}{l}\text { Você sabe } \\
\text { exatamente } \\
\text { quanto deve } \\
\text { em lojas, } \\
\text { cartão de } \\
\text { crédito ou } \\
\text { banco. * }\end{array}$ & 2,12 & 2,48 & $-1,62$ & 0,11 & 0,36 (NS) \\
\hline $\begin{array}{l}\text { É importante } \\
\text { saber } \\
\text { controlar os } \\
\text { gastos da sua } \\
\text { casa. }\end{array}$ & 1,36 & 1,29 & 0,84 & 0,40 & 0,06 (NS) \\
\hline $\begin{array}{l}\text { Média Atitude } \\
\text { ao } \\
\text { Endividamento }\end{array}$ & 2,21 & 2,50 & $-3,22$ & $0,00 * * *$ & 0,29 \\
\hline
\end{tabular}


I Variável invertida. ${ }^{* *}$ Significância ao nível de $1 \%{ }^{* *}$ Significância ao nível de 5\%. *Significância ao nível de 10\%. (NS) Não significativa

Para análise da média de cada dimensão e média geral, as variáveis invertidas passaram pela reversão da escala para que ficassem com o mesmo processo interpretativo que as demais alternativas, que indica que, quanto mais próximo de 5 , maior atitude ao endividamento.

Verificou-se que a média das variáveis de atitude ao endividamento foi de 2,21 e 2,50 para o adimplentes e inadimplentes, respectivamente, mostrando que a amostra não tem uma elevada probabilidade de endividarse, mas que deve atentar-se para elevados níveis de desembolso que possam comprometer sua vida financeira. Em relação aos inadimplentes, estes obtiveram médias estatisticamente significantes superiores de atitude ao endividamento, o que destaca que os beneficiários inadimplentes possuem maior atitude ao endividamento que os adimplentes.

Ressalta-se que as maiores diferenças de média de atitude ao endividamento ocorreram nas variáveis "para você é normal as pessoas ficarem endividadas para pagar suas contas", "você prefere comprar parcelado mesmo que no total saia mais caro" e "as pessoas ficariam desapontadas contigo se soubessem que você tem dívida". Observa-se que as duas primeiras se referem a parcelamentos, que em muitos casos são realizados com grande facilidade, em momentos de impulso, sem serem contabilizados a todas as outras despesas mensais e acabam levando, assim, a situações de endividamento excessivo. A terceira questão, referente ao desapontamento das pessoas, principalmente familiares, em situações de dívidas, acaba sendo uma consequência das duas primeiras, e é um sinal de que há preocupação com a situação financeira familiar.

As questões que também apresentaram diferenças de média significativas entre os adimplentes e inadimplentes, sendo que os inadimplentes apresentaram maior atitude ao endividamento, porém em menor magnitude, foram "você prefere comprar parcelado do que esperar ter dinheiro para comprar à vista" e "é melhor primeiro juntar dinheiro e só depois gastar”. Ressalta-se que essas questões envolvem preferências no tempo, e aquelas pessoas que têm maior pressa para obter determinado bem acabam optando por fazer a compra e, em seguida, realizar os pagamentos, através de cartão de crédito, financiamentos ou carnês mensais. Essas questões tornam-se não prejudiciais ao orçamento quando os parcelamentos são pagos sem atrasos e contabilizados adequadamente nas despesas mensais. Diante disso, podem não apresentar grande diferença de médias entre os adimplentes e inadimplentes.

As afirmações "não é certo gastar mais do que você ganha", "não tem problema ter dívida se você sabe que pode pagar", "você sabe exatamente quanto deve em lojas, cartão de crédito ou banco" e "é importante saber controlar os gastos da sua casa" não apresentaram diferença de média significativa entre os adimplentes e inadimplentes. A grande maioria concorda com as questões "não é certo gastar mais do que você ganha" e "é importante saber controlar os gastos da sua casa". Quanto ao saber exatamente quanto deve em lojas, cartão de crédito ou banco, a maioria dos entrevistados concordaram ou concordaram totalmente, porém o percentual foi menor. Entende-se assim que eles têm noção da importância da equidade entre receitas e despesas e do controle financeiro, porém a dificuldade é colocar isso em prática no dia-a-dia, com pensamento no futuro e imprevistos que podem surgir.

De maneira geral, percebe-se que os inadimplentes tendem a apresentar atitudes ao endividamento mais inadequadas, principalmente ao acharem que é normal as pessoas ficarem endividadas para pagarem suas contas, comprar parcelado, mesmo que no total saia mais caro, e acreditarem menos que é melhor primeiro juntar dinheiro e só depois gastar. Esses resultados salientam o que já foi comentado por Frade et al (2008) e Gathergood (2012), que a busca incessante para satisfazer necessidades e desejos, além da facilidade de acesso ao crédito, faz com que os indivíduos acabem gastando além dos seus recursos, fazendo com que se tornem mais propensos ao endividamento e inadimplência. Outros fatores foram elencados pela Confederação Nacional do Comércio de Bens, Serviços e Turismo - CNC (2015) como causadores de dívidas das famílias: o uso do cartão de crédito, cheque especial ou pré-datado, crédito consignado ou crédito pessoal, carnês e financiamento de carro. As prestações acumulam e ultrapassam a capacidade de pagamento. 
Referente a não ter problema em contrair uma dívida se o beneficiário sabe que pode pagar, para ambos os grupos, a média foi maior que 3,7, demonstrando que os usuários não se atentam para o fato de que podem ocorrer despesas inesperadas, evidenciando maior atitude ao endividamento nessa questão. O Banco Central do Brasil (2014) adverte que as principais causas do endividamento excessivo e inadimplência são a perda de emprego e renda, doença própria e/ou de familiares, morte do responsável pela maior parte da renda familiar, gravidez não programada, separação conjugal, fatos considerados inesperados, demonstrando que deve-se pensar em tais situações e precaver-se. Ambos os grupos investigados têm noção de que não é certo gastar mais do que se ganha e que é importante saber controlar os gastos da casa, demonstrando uma boa atitude ao endividamento nessas questões.

\subsection{Associação entre as variáveis socioeconômicas e de gerenciamento financeiro com a inadimplência no PMCMV}

Para uma análise preliminar da associação entre as variáveis socioeconômicas e de gerenciamento financeiro com a inadimplência no PMCMV, apresenta-se, na Tabela 4, a distribuição do percentual de frequência da variável inadimplência no PMCMV para cada valor das variáveis explicativas com escala nominal ou ordinal. Além disso, na última coluna dessa tabela, reporta-se a medida de associação qui-quadrado de Pearson (valor $\mathrm{p}$ entre colchetes) entre cada par: variável explicativa $\mathrm{x}$ adimplência e inadimplência no PMCMV.É importante mencionar que se trata de uma análise bivariada e que, portanto, a medida de associação entre cada par de variáveis não leva em conta as variações nas demais variáveis explicativas. 
TABELA 4- ADIMPLÊNCIA E INADIMPLÊNCIA NO PMCMV X VARIÁVEIS EXPLICATIVAS

\begin{tabular}{|c|c|c|c|c|}
\hline Variável & Valores & \multirow{2}{*}{$\begin{array}{l}\text { Adimplente } \\
\%\end{array}$} & \multirow{2}{*}{$\begin{array}{l}\text { Inadimplente } \\
\%\end{array}$} & \multirow{2}{*}{$\begin{array}{l}\text { Qui2Pearson } \\
\text { [Valor p] }\end{array}$} \\
\hline \multirow[b]{2}{*}{ Gênero } & Homem & & & \\
\hline & Mulher & bu, uv & $\begin{array}{l}40,00 \\
57,76\end{array}$ & $\begin{array}{l}2,650 \\
{[0,104]}\end{array}$ \\
\hline \multirow{4}{*}{ Idade } & Até 31 anos & 22,000 & 78,00 & \multirow{4}{*}{$\begin{array}{l}24,79 \\
{[0,000]}\end{array}$} \\
\hline & $\begin{array}{l}\text { De } 32 \text { a } 41 \\
\text { anos }\end{array}$ & 33,30 & 66,70 & \\
\hline & $\begin{array}{l}\text { De } 42 \text { a } 55 \\
\text { anos }\end{array}$ & 54,10 & 45,90 & \\
\hline & $\begin{array}{l}\text { Acima de } \\
55 \text { anos }\end{array}$ & 73,70 & 26,30 & \\
\hline \multirow{4}{*}{ Estado Civil } & Casado(a) & 45,00 & 55,00 & \multirow{4}{*}{$9,07[0,028]$} \\
\hline & Solteiro(a) & 34,10 & 65,90 & \\
\hline & Viúvo(a) & 83,30 & 16,70 & \\
\hline & Separado(a) & 45,50 & 54,50 & \\
\hline \multirow{2}{*}{$\begin{array}{l}\text { Possui } \\
\text { dependentes }\end{array}$} & Nẫo & 60,50 & 39,50 & \multirow{2}{*}{$4,81[0,028]$} \\
\hline & Sim & 40,70 & 59,30 & \\
\hline \multirow{4}{*}{ Renda } & $\begin{array}{l}\text { Até } \\
\text { R } \$ 980,00\end{array}$ & 51,30 & 48,70 & \multirow{4}{*}{$2,07[0,557]$} \\
\hline & $\begin{array}{l}\text { De } \\
\mathrm{R} \$ 1.980,01 \\
\mathrm{a} \\
\mathrm{R} \$ 1.400,00\end{array}$ & 35,90 & 64,10 & \\
\hline & $\begin{array}{l}\text { De } \\
\mathrm{R} \$ 1.400,01 \\
\mathrm{a} \\
\mathrm{R} \$ 2.000,00\end{array}$ & 47,80 & 52,20 & \\
\hline & $\begin{array}{l}\text { Acima de } \\
\mathrm{R} \$ 2.000,00\end{array}$ & 45,20 & 54,80 & \\
\hline \multirow{2}{*}{ Dividas. } & $\begin{array}{l}\text { Não possui } \\
\text { dividas. }\end{array}$ & 56,60 & 43,40 & 4,26 \\
\hline & $\begin{array}{l}\text { Possui } \\
\text { dividas }\end{array}$ & 39,20 & 60,80 & {$[0,039]$} \\
\hline \multirow{2}{*}{$\begin{array}{l}\text { Dividas em } \\
\text { atraso. }\end{array}$} & $\begin{array}{l}\text { Não possui } \\
\text { dívidas em } \\
\text { atraso. }\end{array}$ & 60,40 & 39,60 & \multirow{2}{*}{$\begin{array}{l}20,77 \\
{[0,000]}\end{array}$} \\
\hline & $\begin{array}{l}\text { Possui } \\
\text { dívidas em } \\
\text { atraso }\end{array}$ & 23,40 & 76,60 & \\
\hline \multirow{2}{*}{$\begin{array}{l}\text { Possuir } \\
\text { cartão de } \\
\text { crédito. }\end{array}$} & Não. & 38,30 & 61,70 & \multirow{2}{*}{$3,25[0,071]$} \\
\hline & Sim. & 52,70 & 47,30 & \\
\hline \multirow{2}{*}{$\begin{array}{l}\text { Possui carnê } \\
\text { de crediário. }\end{array}$} & Não & 42,50 & 57,50 & \multirow{2}{*}{$0,41[0,525]$} \\
\hline & Sim. & 47,60 & 52,40 & \\
\hline \multirow[t]{2}{*}{ Gastos. } & $\begin{array}{l}\text { Gasta } \\
\text { menos ou } \\
\text { igual ao } \\
\text { que ganha. }\end{array}$ & 54,10 & 45,90 & \multirow[t]{2}{*}{$8,09[0,004]$} \\
\hline & $\begin{array}{l}\text { Gasta mais } \\
\text { que ganha. }\end{array}$ & 30,40 & 69,60 & \\
\hline \multirow{2}{*}{$\begin{array}{l}\text { Situação do } \\
\text { dinheiro. }\end{array}$} & $\begin{array}{l}\text { Geralmente, } \\
\text { pagam } \\
\text { todas as } \\
\text { contas } \\
\text { mensais. }\end{array}$ & 54,80 & 45,20 & \multirow{2}{*}{$\begin{array}{l}15,94 \\
{[0,000]}\end{array}$} \\
\hline & $\begin{array}{l}\text { Geralmente, } \\
\text { não } \\
\text { conseguem } \\
\text { pagar todas } \\
\text { as contas } \\
\text { mensais. }\end{array}$ & 17,90 & 82,10 & \\
\hline \multirow{2}{*}{$\begin{array}{l}\text { Controla } \\
\text { dos gastos. }\end{array}$} & $\begin{array}{l}\text { Mantém } \\
\text { controle } \\
\text { sobre seus } \\
\text { gastos. }\end{array}$ & 46,40 & 53,60 & \multirow[b]{2}{*}{$0,75[0,386]$} \\
\hline & $\begin{array}{l}\text { Não } \\
\text { costuma } \\
\text { controlar } \\
\text { seus gastos. }\end{array}$ & 35,30 & 64,70 & \\
\hline Poupança. & $\begin{array}{l}\text { Já fez ou } \\
\text { está } \\
\text { fazendo. }\end{array}$ & 51,40 & 48,60 & $2,11[0,147]$ \\
\hline & $\begin{array}{l}\text { Não, nunca } \\
\text { fez. }\end{array}$ & 39,80 & 60,20 & \\
\hline Nome ligado & Não. & 77,40 & 22,60 & 16,28 \\
\hline $\begin{array}{l}\text { ao cadastro } \\
\text { negativo. }\end{array}$ & Sim. & 37,10 & 62,90 & {$[0,000]$} \\
\hline Empréstimo & Não. & 50,00 & 50,00 & \\
\hline do nome. & Sim. & 41,20 & 58,80 & $1,21[$ \\
\hline
\end{tabular}


A partir da medida de associação apresentada, pode-se observar que há uma relação de dependência estatisticamente significativa ao nível de 5\% entre a inadimplência no PMCMV e as seguintes variáveis: idade, estado civil, possui dependentes, dívidas, dívidas em atraso, gastos e nome ligado ao cadastro negativo. Entre os indivíduos solteiros, há uma maior proporção de indivíduos inadimplentes no PMCMV (65,9\%) do que entre os casados (55\%), separados (54,5\%) e viúvos (16,7\%). Esses resultados contrariam a pesquisa de Locatelli et al (2015), o qual identificou que a inadimplência no PMCMV é maior para os mutuários casados.

Todavia, corroboram com os resultados de Gathergood (2012) e Vieira, Flores e Campara (2015), os quais observaram que os indivíduos solteiros possuem maior propensão ao endividamento e possuem maiores níveis de sobre-endividamento.

Entre os indivíduos com até 31 anos e de 32 a 41 anos, há uma proporção maior de indivíduos inadimplentes (78\% e 66,7\%, respectivamente) do que entre os indivíduos de 42 a 55 anos e acima de 55 anos (45,9\% e 26,30\%, respectivamente), ou seja, a proporção de indivíduos com alto nível de inadimplência no PMCMV decresce com o aumento da idade, indo de encontro aos resultados de Locatelli et al. (2015) e ratificando estudos anteriores, como os de Ponchio (2006) e Vieira, Flores e Campara (2015), os quais observaram que os indivíduos mais velhos tendem a possuir menores níveis de endividamento. No mesmo sentido, Worthy, Jonkman e Blinn-Pike (2010) destacam que jovens de 18 a 25 anos são mais predispostos a assumir riscos maiores e apresentar menor estabilidade financeira, o que pode explicar a maior vulnerabilidade à dívida.

Entre os indivíduos com dependentes há uma proporção maior com a inadimplência (59,3\%) do que entre os indivíduos sem dependentes (39,5\%), resultado em linha com estudos de Keese (2012), Silva (2011), Godwin (1990) e Lea, Webley e Walker (1995), os quais evidenciam que as famílias com maior número de filhos e dependentes, principalmente crianças, contraem maiores níveis de endividamento, em decorrência do aumento de gastos com situações imprevisíveis como doenças. Entre os indivíduos que possuem dívidas há uma proporção maior com alto nível de inadimplência (60,8\%) do que entre os indivíduos que não possuem dívidas $(43,4 \%)$. Entre os indivíduos que possuem dívidas em atraso há uma proporção maior com alto nível de inadimplência $(76,6 \%)$ do que entre os indivíduos que não possuem dívidas em atraso (39,6\%). Esses resultados são consistes com os estudos de Frade et al (2008) e Marques e Frade (2004).

Entre os indivíduos que gastam mais do que ganham há uma proporção maior com alto nível de inadimplência $(69,6 \%)$ do que entre os indivíduos que gastam menos ou igual ao que ganham (45,9\%), em função de que, ao possuírem mais despesas do que receitas, consequentemente não iriam conseguir arcar com o pagamento de todas as dívidas, inclusive a da prestação da casa. Entre os indivíduos que geralmente não conseguem pagar todas as despesas mensais há uma proporção maior com alto nível de inadimplência $(82,1 \%)$ do que entre os indivíduos que geralmente pagam todas as despesas mensais (45,2\%). Entre os indivíduos que tem ou já tiveram o nome ligado ao cadastro negativo, há uma proporção maior com alto nível de inadimplência $(62,9 \%)$ do que entre os indivíduos que nunca tiveram (22,6\%). Esses achados vão ao encontro do que Sehn e Carlini Junior (2007) observaram em sua pesquisa sobre inadimplência em financiamento habitacional, que muitos mutuários comprometem um percentual muito grande de sua renda com o parcelamento da residência, dificultando os pagamentos atuais e futuros, além de a habitação não estar entre as prioridades de quitação quando o orçamento diminui.

Por fim, com o intuito de verificar o grau dessas associações, foram realizados os testes estatísticos Fi, V de Cramer e Coeficiente de Contigência (Tabela 5), onde, para variáveis com mais de duas categorias, deve-se analisar o V de Cramer e, quando tem apenas duas, o Fi. Para os casos de variáveis com mais de duas categorias e que o Fi seja maior que um, usa-se o Coeficiente de Contigência. 
Tabela 5- Grau de associação da inadimplência no PMCMV x variáveis explicativas.

\begin{tabular}{|c|c|c|c|c|}
\hline \multirow{2}{*}{ Variáveis } & \multicolumn{2}{|l|}{$\mathrm{Fi}$} & \multicolumn{2}{|c|}{ V de Cramer } \\
\hline & Valor & Sig. & Valor & Sig. \\
\hline Idade & 0,400 & 0,000 & 0,400 & 0,000 \\
\hline Estado Civil & 0,242 & 0,028 & 0,242 & 0,028 \\
\hline $\begin{array}{l}\text { Possui } \\
\text { dependentes }\end{array}$ & 0,179 & 0,028 & 0,179 & 0,028 \\
\hline Dividas & 0,166 & 0,039 & 0,166 & 0,039 \\
\hline $\begin{array}{l}\text { Dividas em } \\
\text { atraso }\end{array}$ & 0,366 & 0,000 & 0,366 & 0,000 \\
\hline Gastos & 0,229 & 0,004 & 0,229 & 0,004 \\
\hline $\begin{array}{l}\text { Situação do } \\
\text { dinheiro }\end{array}$ & 0,322 & 0,000 & 0,322 & 0,000 \\
\hline $\begin{array}{l}\text { Nome ligado } \\
\text { ao cadastro } \\
\text { negativo }\end{array}$ & 0,324 & 0,000 & 0,324 & 0,000 \\
\hline
\end{tabular}

Para as variáveis idade e estado civil, por possuírem mais de duas categorias, analisou-se o V de Cramer, o qual mostrou-se significativo ao nível de $5 \%$ para ambas, com relação positiva em relação à inadimplência no PMCMV. Para as variáveis referentes a presença de dependentes, dívidas, dívidas em atraso, gastos, situação do dinheiro e nome ligado ao cadastro negativo, utilizou-se a estatística Fi, dado que possuem apenas duas categorias. Todas elas mostraram-se também significativas ao nível de $5 \%$ e com relação positiva com a inadimplência no PMCMV.

As variáveis que apresentaram maior grau de associação, considerada média, foram as relativas a idade, onde quanto mais novos os indivíduos, maior a inadimplência no PMCMV (0,400), dívidas em atraso $(0,366)$, nome ligado ao cadastro negativo $(0,324)$, situação do dinheiro, em que geralmente não são pagas todas as despesas mensais $(0,322)$ e estado civil, em que os solteiros são mais propensos a maiores níveis de inadimplência no PMCMV $(0,242)$. Já as que apresentaram menor grau de associação foram as variáveis ligadas à contração de dívidas $(0,166)$, à presença de dependentes $(0,179)$ e à presença de gastos, quando os indivíduos gastam mais do que ganham $(0,229)$.

\section{CONSIDERAÇÕES FINAIS}

A moradia é uma necessidade básica de todos os indivíduos e o PMCMV tem colaborado nessa questão, tornando possível que pessoas com pouca ou nenhuma possibilidade tenham acesso a esse bem tão importante. Contudo, o problema da inadimplência vem aumentando na Faixa 1, dado que os percentuais de inadimplência nos anos de 2014, 2015 e 2016, tendo o mês de maio como referência, estavam em 16,8\%, 22,2\% e 26,55\% respectivamente (CGU, 2016). Assim, verificar as razões para o aumento da inadimplência, analisar as práticas de gerenciamento financeiro e identificar o grau de associação entre a inadimplência no PMCMV e variáveis socioeconômicas e de gerenciamento financeiro, auxiliou no cumprimento do objetivo do estudo que foi fazer um retrato dos inadimplentes do PMCMV.

Verificou-se que o percentual de inadimplência na Faixa 1, divulgado pelo Ministério das Cidades, é muito parecido com o que foi encontrado na pesquisa para a cidade de Santa Maria (RS). Quanto aos motivos que levam ao atraso das prestações, destacou-se o uso do dinheiro que seria para o pagamento da prestação em despesas inesperadas, devido a problemas com doenças e/ou desemprego e motivos como o atraso do envio dos boletos, em que diversos entrevistados relataram que os mesmos não chegam até a data do vencimento em suas residências e que eles têm que se deslocar até uma agência da CEF para pegá-lo. Em relação ao perfil dos inadimplentes, observou-se que a maioria é mulher, com até 41 anos, casadas ou solteiras, que possuem 
dependentes, com escolaridade entre Ensino Fundamental e Ensino Médio, sendo a maioria com renda familiar mensal de até R \$1.400,00.

Quanto às características de gerenciamento financeiro dos inadimplentes, a maioria possui outras dívidas além do financiamento do PMCMV e dívidas em atraso, gasta menos ou igual ao que ganha, contudo, muitos gastam mais que do ganham. Referente à poupança, a maior parte dos entrevistados nunca conseguiu fazer e o percentual de indivíduos que têm o nome ligado ao cadastro negativo mostrou-se bastante expressivo. Percebe-se que os inadimplentes no PMCMV tendem a ter piores atitudes ao endividamento, principalmente ao acharem que é normal as pessoas ficarem endividadas para pagarem suas contas, comprar parcelado, mesmo que no total saia mais caro, e acreditarem menos que é melhor primeiro juntar dinheiro e só depois gastar.

A partir da medida de associação apresentada, pode-se observar que os indivíduos solteiros, com até 41 anos, que possuem dependentes, com dívidas e com dívidas em atraso, que gastam mais do que ganham, que geralmente não conseguem pagar todas as despesas mensais e que têm ou já tiveram o nome ligado ao cadastro negativo apresentam maior tendência a tornarem-se inadimplentes no PMCMV (Faixa 1).

Tais conclusões sugerem a urgência e a necessidade de serem desenvolvidas ações efetivas e direcionadas para minimizar o problema de inadimplência no PMCMV, dado que o país passa por uma crise financeira que não permite ao governo ser passível, já que até 95\% do valor do imóvel é bancado pelo dinheiro público e a escassez de recursos públicos vem afetando fortemente o país. Uma das possíveis medidas a serem tomadas refere-se a um maior comprometimento dos responsáveis pela implantação do PMCMV nas cidades, com as ações de incentivo para uma melhora no Planejamento e Gestão do Orçamento Familiar, as quais estão previstas no desenho normativo do Programa.

Essas ações referem-se à divulgação de informações sobre organização e planejamento do orçamento familiar, racionalização dos gastos com moradia e orientação às famílias sobre as tarifas sociais dos serviços públicos. Ainda devem ser abordados temas sobre geração de trabalho e renda, como ações de mapeamento de vocações dos beneficiários e atividades produtivas do entorno do empreendimento e região, encaminhamento aos serviços de intermediação de mão de obra por meio dos sistemas de emprego e promoção de projetos de capacitação para o trabalho.

Resumidamente, sugere-se a articulação entre diversos programas sociais, aproximando as famílias atendidas pelo PMCMV dos Sistemas Nacionais de Emprego (SINEs), do Programa Bolsa Família, das Farmácias Populares, entre outros que auxiliem na manutenção da empregabilidade e renda, auxiliando o cumprimento das obrigações financeiras, como a prestação da casa própria. Ressalta-se que, para indivíduos de baixa renda, torna-se essencial que seja oferecido suporte para que as famílias possuam uma vida digna, já que um importante passo foi dado, o acesso à moradia.

Como principal contribuição da pesquisa, destaca-se que este estudo é pioneiro em identificar os motivos da inadimplência no PMCMV e ao propor variáveis socioeconômicas e de gerenciamento financeiro que influenciam nos elevados níveis de inadimplência no PMCMV. Com isso, entre outras iniciativas, podemse desenvolver ações para diminuir o percentual de inadimplentes da Faixa 1 do PMCMV, trabalhando sobre o perfil que apresenta maiores chances de inadimplência. Todavia, como limitação tem-se o fato de as informações da pesquisa proverem da percepção do indivíduo, que podem sofrer vieses dadas as interpretações do respondente.

\section{REFERÊNCIAS}

Andrade, G. V. M. (2012). Políticas habitacionais brasileiras: uma avaliação do Programa minha casa minha vida em suas duas edições (Monografia). Universidade Federal do Rio de Janeiro, Rio de Janeiro, RJ, Brasil.

Associação Brasileira de Cohabs e Agentes Públicos de Habitação (2016). CAIXA estuda ações para diminuir inadimplência no Programa Minha Casa, Minha Vida. Recuperado de http://www.abc.habitacao.org.br/ index.php/caixa-estuda-acoes-para-diminuir-inadimplencia-no-Programa-minha-casa-minha-vida/ 
Braido, G. M. (2014). Planejamento Financeiro Pessoal dos Alunos de Cursos da Área de Gestão: estudo em uma instituição de ensino superior do Rio Grande do Sul. Revista Estudo \& Debate, 21(1).

Brandão, F. (2014). Inadimplência é maior na baixa renda do Minha Casa, Minha Vida. Gazeta do Povo, 08 jun. Recuperado de http://www.gazetadopovo.com.br/economia/inadimplencia-e-maior-na-baixa-renda-dominha-casa-minha-vida-9ayv2ssyww2ti6tool7sfp4r2

Brasil (2014). Ministério das Cidades/Secretaria de Assuntos Estratégicos da Presidência da República. Pesquisa de satisfação dos beneficiários do Programa Minha Casa Minha Vida. Recuperado de http://repositorio.ipea.gov.br/bitstream/11058/3298/1/Pesquisa\%20de\%20satisfa\%C3\%A7\%C3\%A3o \%20dos\%20benefici\%C3\%A1 rios\%20do\%20Programa\%20Minha\%20Casa\%20Minha\%20Vida.pdf

Caixa Econômica Federal (CEF, 2015). Manual do Programa Minha Casa Minha Vida- Entidades Recursos FDS. Recuperado de http://www.caixa.gov.br/Downloads/habitacao-minha-casa-minha-vida/ MANUAL_MCMV_ENTIDADES.pdf

Campara, J. P. (2016). Beneficiários do Programa Bolsa Família: uma análise sob a óptica comportamental e financeira em municípios gaúchos (Dissertação de Mestrado). Universidade Federal de Santa Maria, Santa Maria, RS, Brasil.

Canova, L., Rattazzi, A. M. M., \& Webley, P. (2005). The hierarchical structure of saving motives. Journal of Economic Psychology, 26(1), 21-34.

Cenci, J. J., Pereira, I., \& Barichello, R. (2015). Educação financeira, planejamento familiar e orçamento doméstico: um estudo de caso. Revista Tecnológica, 3(2), 89-104.

CGU (2016). Ministério da Transparência e Controladoria-Geral da União. Recuperado de http://www.consultaesic.cgu.gov.br/busca/dados/Lists/Pedido/Attachments/487700/ RESPOSTA_PEDIDO_PMCMV.xls

Confederação Nacional do Comércio de Bens, Serviços e Turismo (CNC, 2015). Pesquisa Nacional de Endividamento e Inadimplência do Consumidor (PEIC) - dezembro 2015. Recuperado de http://www.cnc.org.br/central-do-conhecimento/pesquisas/economia/pesquisa-nacional-deendividamento-e-inadimplencia-do--13

Cucolo, E. (2015). Cresce calote no Minha Casa, Minha Vida. Recuperado de http://www1.folha.uol.com.br/ mercado/2015/06/1636053-cresce-calote-no-minha-casa-minha-vida.shtml

Cunha, S. (2012). Programa "Minha Casa, Minha Vida" em Parnamirim-RN: uma avaliação de impacto a partir da satisfação dos moradores do residencial Iderval Medeiros (Monografia). Universidade Federal do Rio Grande do Norte, Natal, RN, Brasil.

D’amico, F. (2011). O Programa Minha Casa Minha Vida e a CAIXA. In Costa, J. C. et al. O desenvolvimento econômico brasileiro e a CAIXA: trabalhos premiados. p. 33-54. Rio de Janeiro: Centro Internacional Celso Furtado de Políticas para o Desenvolvimento.

Field, A. (2009). Descobrindo a estatística usando o SPSS-2. Bookman Editora.

Flores, S. A. M. (2012) Modelagem de equações estruturais aplicada à propensão ao endividamento: uma análise de fatores comportamentais (Dissertação de Mestrado). Universidade Federal de Santa Maria, Santa Maria, RS, Brasil.

Frade, C. et al. (2008). Um perfil dos sobre-endividados em Portugal. Portugal: Centro de Estudos Sociais. Faculdade de Economia de Coimbra.

Gathergood, J. (2012). Self-control, financial literacy and consumer over-indebtedness. Journal of Economic Psychology, 33(3), 590-602.

Godwin, D. D. (1990). Family financial management. Family Relations, 39(2), 221-228.

Guilhen, A. J., \& Meireles, E. (2017). Programa Minha Casa Minha Vida: o fundo garantidor da habitação popular e os obstáculos à consecução da cobertura por perda de renda. Revista Eletrônica Engenharia Estudos e Debates.

Keese, M. (2012). Who feels constrained by high debt burdens? Subjective vs. objective measures of household debt. Journal of Economic Psychology, 33(1), 125-141. 
Keese, M., \& Schmitz, H. (2011). Broke, ill, and obese: The effect of household debt on health. Recuperado de http:// papers.ssrn.com/sol3/papers.cfm?abstract_id $=1750216$

Krause, C., Balbim, R., \& Neto, V. C. L. (2013). Minha Casa Minha Vida, nosso crescimento: Onde fica política habitacional? (No. 1853). Texto para Discussão, Instituto de Pesquisa Econômica Aplicada (IPEA).

Lea, S. E., Webley, P., \& Walker, C. M. (1995). Psychological factors in consumer debt: Money management, economic socialization, and credit use. Journal of economic psychology, 16(4), 681-701.

Leal, C. P., \& do Nascimento, J. A. R. (2015). Planejamento financeiro pessoal. Revista de Ciências Gerenciais, 15(22), 163-183.

Linardi, F. M (2008). Avaliação dos determinantes macroeconômicos da inadimplência bancária no Brasil. (Dissertação de Mestrado). Universidade Federal de Minas Gerais, Belo Horizonte, MG, Brasil.

Lobler, M. L.; Santos, E. L.; Scherer, F. L.; Fernandes, G. K. (2000). A inadimplência nos contratos de financiamento habitacional. Anais do XX Encontro Nacional de Engenharia de Produção (ENEGEP).

Locatelli, R. L.; Ramalho, W.; Silvério, R. A.O. Determinantes da inadimplência no crédito habitacional direcionado à classe média emergente brasileira. Revista de Finanças Aplicadas, (1), 1-30.

Marques, M. M. L. (2000). O endividamento dos consumidores. Coimbra: Almedina.

Marques, M. M. \& Frade, C. (2004). Regular o sobreendividamento. Gabinete de Política Legislativa e Planejamento do Ministério da Justiça (Ed.), Código da Insolvência e da Recuperação de Empresas. Coimbra: Coimbra Editora.

Martins, G. A. (2011). Estatística geral e aplicada (4a ed.). São Paulo: Atlas.

Mattar, F. (2005). Pesquisa de Marketing: metodologia e planejamento (6a ed.). São Paulo: Atlas.

Mendes-Da-Silva, W., Nakamura, W. T., \& Moraes, D. C. D. (2012). Credit card risk behavior on college campuses: evidence from Brazil. BAR-Brazilian Administration Review, 9(3), 351-373.

Merigo, J., \& Rockenbach, V. (2004). Política habitacional e a identificação do (s) motivo (s) da inadimplência das famílias beneficiadas com o Programa de Terrenos. Textos \& Contextos (Porto Alegre), 3(1), 1-21.

Ministério do Desenvolvimento Social e Combate à Fome; Secretaria de Avaliação e Gestão da Informação (MDS; SAGI, 2014). Pesquisa sobre os conhecimentos, atitude e práticas das famílias inscritas no cadastro único para Programas sociais. Cadernos de Estudo, n. 16, Brasília: Indago.

Miotto, A. P. S. C. (2013). Antecedentes e consequências da gestão das finanças domésticas: uma investigação com consumidores da classe (Tese de Doutorado) Fundação Getúlio Vargas, São Paulo, SP, Brasil.

Moreira, V. S. \& Silveira, S. D. F. R. (2015). Indicadores de desempenho do Programa Minha Casa, Minha Vida: avaliação com base na satisfação dos beneficiários. Cadernos Gestão Pública e Cidadania, 20(66).

Moura, J. M. (2014). O Programa Minha Casa, Minha Vida na Região Metropolitana de Natal: uma análise espacial dos padrões de segregação e desterritorialização. Revista Brasileira de Gestão Urbana, 6(3), 339-359.

Muller, K. O. (2010). Sociedade de consumo e cultura do endividamento: estudo de caso sobre compradores compulsivos em Porto Alegre, RS (Monografia). Universidade Federal do Rio Grande do Sul, Porto Alegre, RS, Brasil.

Olivato, H. \& Souza, P. K. L. (2007). Endividamento: Um Estudo Preliminar dos Fatores Contribuintes. Anais do Encontro Científico e Simpósio de Educação Unisalesiano, Lins, SP, Brasil.

Pestana, M. H. \& Gageiro, J. N. (2008). Análise de dados para ciências sociais: a complementaridade do SPSS. Lisboa: Edições Sílabo.

Plagnol, A. C. (2011). Financial satisfaction over the life course: The influence of assets and liabilities. Journal of Economic Psychology, 32(1), 45-64.

Ponchio, M. C. (2006). The Influence of Materialism on Consumption Indebtedness in the Context of Low Income Consumers From the City of Sao Paulo (Tese de Doutorado). Fundação Getúlio Vargas, São Paulo, SP, Brasil.

Portal Brasil (2015). MCMV 3 amplia subsídios para renda de até R\$ 2,3 mil. Recuperado de http:// www.brasil.gov.br/infraestrutura/2015/09/mcmv-3-amplia-subsidios-para-renda-ate-r-2-3-mil

Portal Brasileiro de Dados Abertos (2015). Indicadores sobre Minha Casa Minha Vida. Recuperado de http:// dados.gov.br/dataset/minha-casa-minha-vida 
Portaria no 168/2013 de 12 de Abril. Diário Oficial da União de 15.04.13 - Dispõe sobre as diretrizes gerais para aquisição e alienação de imóveis com recursos advindos da integralização de cotas no Fundo de Arrendamento Residencial - FAR, no âmbito do Programa Nacional de Habitação Urbana - PNHU, integrante do Programa Minha Casa, Minha Vida - PMCMV.

Ramos, J. S. \& Noia, A. C. (2015). A Construção de Políticas Públicas em Habitação e o Enfrentamento do Déficit Habitacional no Brasil: uma análise do Programa Minha Casa Minha Vida. Desenvolvimento em Questão, 14(33), 65-105.

Rego, W. D. L., \& Pinzani, A. (2013). Liberdade, dinheiro e autonomia. O caso da Bolsa Família. Política \& Trabalho, (38).

Rizek, C. S., Amore, C. S. \& de Camargo, C. M. (2014). Política social, gestão e negócio na produção das cidades: o Programa Minha Casa Minha Vida “entidades”. Caderno CRH, 27(72), 531-546.

Santos, A. C., \& Silva, M. (2014). Importância do planejamento financeiro no processo de controle do endividamento familiar: um estudo de caso nas regióes metropolitanas da Bahia e Sergipe. Revista Formadores, 7(1), 05-17.

Sehn, C. F., \& Carlini Junior, R. J. (2007). Inadimplência no sistema financeiro de habitação: um estudo junto à Caixa Econômica Federal (CAIXA). RAM. Revista de Administração Mackenzie, 8(2).

Shimizu, J. Y. (2010). Projeção de impactos econômicos do Programa Minha Casa, Minha Vida: uma abordagem de equilíbrio geral computável (Dissertação de Mestrado). Universidade Federal de Minas Gerais, Belo Horizonte, MG, Brasil.

Shockey, S. S. (2002). Low-wealth adults financial literacy, money management behavior and associates factors, including critical thinking (Tese de Doutorado). Universidade de Utah,Utah, Estados Unidos.

Silva, P. R. (2011). Psicologia do risco de crédito: análise da contribuição de variáveis psicológicas em modelos de credit scoring (Tese de Doutorado). Universidade de São Paulo, São Paulo, SP, Brasil.

Souza, E. M. S.; Mello, S. P. T. Avaliação do Impacto Financeiro para os Beneficiários do Programa Minha Casa Minha Vida em um Município na Região Sul do Brasil. Anais do IV Encontro Brasileiro de Administração Pública, João Pessoa, Paraíba, Brasil.

Tolotti, M. (2007). As armadilhas do consumo: acabe com o endividamento. Elsevier.

Trindade, L. L., Righi, M. B., \& Vieira, K. M. (2012). De onde vem o endividamento feminino? Construção e validação de um modelo PLS-PM. Revista Eletrônica de Administração, 18(3), 718-746.

Vieira, K. M., Flores, S. A. M., Kunkel, F. R., \& Campara, J. P. (2014). Níveis de Materialismo e Endividamento: Uma Análise de Fatores Socioeconômicos na Mesorregião Central do Estado no Rio Grande Do Sul. Revista de Administração, Contabilidade e Economia da Fundace, 5(2).

Vieira, K. M., Flores, S. A. M., \& Campara, J. P. (2015). Propensão ao Endividamento no Município de Santa Maria (RS): verificando diferenças em variáveis demográficas e culturais. TPA-Teoria e Prática em Administração, 4(2), 180-205.

Wang, L., Lu, W., \& Malhotra, N. K. (2011). Demographics, attitude, personality and credit card features correlate with credit card debt: A view from China. Journal of economic psychology, 32(1), 179-193.

Worthy, S. L., Jonkman, J., \& Blinn-Pike, L. (2010). Sensation-seeking, risk-taking, and problematic financial behaviors of college students. Journal of Family and Economic Issues, 31(2), 161-170.

Zerrenner, S. A. (2007). Estudo sobre as razões para a população de baixa renda (Dissertação de Mestrado). Universidade de São Paulo, São Paulo, SP, Brasil.

\section{BY-NC-ND}

